\title{
Case Study Of Omnichannel Marketing in PT Arwana Citramulia Tbk
}

\author{
Taufik Amirullah ${ }^{1}$ and Daniel Tumpal H. Aruan ${ }^{1}$
}

\begin{abstract}
Omnichannel marketing is a marketing method that integrates marketing channels to target specific target markets. This research is a case study of the use of omnichannel marketing for B2B activities at PT Arwana Citramulia Tbk, the largest company of many companies in the ceramics industry in Indonesia. PT Arwana Citramulia Tbk targets the middle to lower market segments throughout Indonesia. To be able to dissect how PT Arwana Citramulia Tbk manages its channel, this research will use qualitative methods by conducting unstructured interviews with various stakeholders in PT Arwana Citramulia Tbk. In addition, technology acceptance models are also used to measure revenue from the distribution chain line of PT Arwana Citramulia Tbk, which conducts B2B marketing activities towards the use of online channels to support the use of omnichannel marketing. The technology acceptance model will be used to analyze quantitatively, which is also equipped with results of unstructured interviews regarding the implementation and management of omnichannel marketing by PT Arwana Citramulia Tbk. This research shows that the integration between channels used by PT Arwana Citramulia Tbk is inseparable from the existence of vision, mission, strategy and adequate resources from the top management level to the frontliners.
\end{abstract}

Keywords-Omnichannel Marketing, Technology Acceptance Model, Marketing Channel, B2B Marketing, PT Arwana Citramulia.

\section{INTRODUCTION}

Technological developments in the industrial era 4.0, or the era of the internet of things, have led to changes in various human lifestyles, including business people from producers to consumers. Internet of things or IoT is the term that was first used by Germany to mention industrial development that aims to change working and living environments, which use digital technology in the value chain for production and fulfillment of life needs [1]. IoT is a threat to those who do not have the ability to adapt to technological advances but can be a form of innovation for others [2].

IoT changes the fundamentals of a business and occurs in all types and lines of business. Research results from [1] show that SMEs are more adaptable to digitalization in the industrial era 4.0 with different forms of adaptation, so that companies that already mature and has great assets, IoT is a challenge in itself where companies must be able and

\footnotetext{
${ }^{1}$ Taufik Amirullah and Daniel Tumpal H. Aruan are with Magister of Management University of Indonesia, Jakarta, Indonesia. E-mail: amirullah1352@gmail.com; dtumpal@yahoo.com.
}

willing to invest to be able to adjust to existing technological changes. IoT also causes changes in all forms of industry, even to the food industry in the agricultural sector, such as by using sensors that are connected with applications to monitor humidity levels of rice fields and carry out irrigation [2].

The impact of IoT in the field of marketing lies in the use of channels that can be used by business units in carrying out the 3 marketing channel functions. If previously the marketing channel model was linear in carrying out the functions of communication, service, and distribution [3], technological developments led to the emergence of other options for marketing their products. The existence of technology in the IoT era can also reduce marketing channels that are linear in nature so that consumers can immediately gain access toproducers without going through agents, wholesalers, or retailers. Technology development and digitalization in the IoT era encouraged the formation of new options to market their products, one of which was to use the internet and various types of digital platforms to cut costs and maximize the value chain. Sellers can use different channels to obtain and retain customers, to develop markets [4]. The use of these different channels includes multichannel marketing, where when different channel uses are integrated, it will become a marketing method called hybrid [3] or omnichannel marketing [4].

The use of omnichannel marketing is a new marketing method that is developing, which aims to increase the shopping experience of customers, both to provide convenience, to provide satisfaction in shopping which can later provide more value for customers [1]. As a development of multichannel marketing, companies that start using integration between channels, or omnichannel marketing, strive to provide quality consistency of both products and services from each channel used [2]. Research conducted by [5] regarding the use of omnichannel marketing in the form of integration between online channels and offline stores provides added value for customers. The research conducted in France shows that touch points, consistency, and smoothness in shopping are obtained when the channels provided are integrated to provide value for customers.

The development of omnichannel marketing provides an option for marketers to be able to provide added value to their customers through marketing channels. Even though it seems that omnichannel marketing provides added value 
in several studies, other research conducted by Zhang, Ren, Wang, \& He shows that the added value created is inseparable from how customers perceive service. In this study, PT Arwana Citramulia Tbk, a ceramic company that has the largest market share in Indonesia will be the main subject. PT Arwana Citramulia Tbk has a market share of the lower middle class, which has different characteristics from a number of pre-existing research samples on omnichannel [1], [3]-[5].

This case study formulated a number of problems that will be discussed in this study. The first problem formulation raised by researchers is how PT Arwana Citramulia Tbk adapted to new technology in the era of IoT or Industry 4.0. This problem will be examined by looking at how the salesperson as the channel agents that act as the technology user can integrate the tools that PT Arwana Citramulia Tbk provide with their B2B marketing activities. This problem formulation will be in the form of a question sentence in the form of: "How do large retail distributors and stores use the channels provided by PT Arwana Citramulia Tbk in their B2B marketing activities?".

The second one is carry out in the form of problem statement; "How does PT Arwana Citramulia Tbk apply channel usage in an integrated manner to the entire distribution chain below". This question will answered with qualitative information about how PT Arwana Citramulia Tbk integrate their marketing channel, including promoting the use of technology in their marketing channel to obtain superiority over the competitor. PT Arwana Citramulia Tbk is choosen as the subject because while in 2017-2018 the ceramic industry declining, PT Arwana Citramulia Tbk can improve their net sales and seize the market. With the usage of technology, complemented with innovation in their vision-mission statement and strategy, PT Arwana Citramulia Tbk can achieve sustainable competitive advantage, especially in terms of marketing channel.

\section{A. PT Arwana Citramulia Tbk Profile}

PT Arwana Citramulia Tbk is a company engaged in the ceramic industry. The ceramic products produced by PT Arwana Citramulia Tbk are certified by the Indonesian National Standard, with various operational aspects which also meet various ISO standards, such as ISO 9001 for Quality Management Systems, ISO 13006 for Ceramic Tiles - Definitions, Classification, Characteristics and Marking, and ISO 14001 for the Environmental Management System. PT Arwana Citramulia Tbk began with ratification as a business legal entity in the form of a limited liability company on February 22, 1993. PT Arwana Citramulia Tbk operates commercially on June 23, 1995, with initial production starting at Plant I, located in Pasar Kemis, Tangerang. Plant I currently has a production capacity of 2.88 million square meters per year [6].

The vision and mission of PT Arwana Citramulia Tbk is the guideline of how the company acts so that it indirectly plays a role in how PT Arwana Citramulia Tbk uses different channels in an integrated manner to target the same target market, known as omnichannel marketing. Quoting from the annual report of PT Arwana Citramulia Tbk in 2018, PT Arwana Citramulia Tbk has a vision in the form of:

\section{"Being the best company in the ceramics industry, full of creativity and innovation, and able to contribute meaningfully to the development of the country and society"}

This vision is created by the idealism of the founder of the company which is also a form of commitment to the community. PT Arwana Citramulia Tbk sees the context of 'being the best' not only from a business perspective but from social responsibility as a company to society in general. In addition, PT Arwana Citramulia Tbk also instills innovation and creativity in its vision, which is then clarified with the following mission:

\section{"Upholding the quality of products and services by applying the principle of efficiency consistently, so as to be able to produce quality ceramics at affordable prices"}

PT Arwana Citramulia Tbk targets the middle to lower market so that to be able to sell quality products, both in terms of goods and services, PT Arwana Citramulia Tbk is required to be able to innovate, one of which is by investing in technology and human resources to achieve company goals.

"Implementing a dynamic, creative and innovative production process"

PT Arwana Citramulia Tbk again emphasizes the production process to be dynamic, creative and innovative. Regarding products, this is, of course, to be able to create products according to market trends with a variety of patterns and various ceramics.

\section{"Creating a business climate that is able to absorb local energy and develop related mid-scale businesses."}

Vision shows where the company will be developed, which is supported by the existence of missions that reinforce the scope and purpose of a business activity, related to 'what we do', 'who we are', and 'why are we here' from the company [7].

Regarding the vision of PT Arwana Citramulia Tbk, which aims to be useful for the community, PT Arwana Citramulia Tbk is committed to synergizing with the progress of the local economy by prioritizing the use of raw material sources close to the factory, employing local workers, and synergizing with medium-scale businesses. The vision and mission of PT Arwana Citramulia Tbk will then be seen in this research, especially those relating to the management of marketing channels used by PT Arwana Citramulia Tbk. 
PT Arwana Citramulia Tbk in 2018 implemented various strategies and policies in order to develop businesses to achieve company goals. Every strategy and policy implemented includes aspects of management, marketing, finance, operations, information systems, research and development companies. Some business policies are divided into 1) production and operations, and; 2) products, marketing, research and development.

\section{B. Production and Operations}

- To expand production strategically and measurably to improve the Company's economies of scale.

- Priority program consisting of strengthening logistics functions, consolidation of human resources, strengthening clay supply, lean manufacturing, preventive maintenance, and compliance.

- Fix and modernize the management of finished goods warehouses to minimize costs, distribution barriers, and potential irregularities.

- Controlling the planned and anticipated supply of raw materials to support production stability and quality.

- Explore new sources of efficiency.

C. Product, Marketing, Research and Development

- Strengthening the Company's existence in the ceramic market by increasing the sales portion of UNO products in the Arwana mix product.

- Explore new innovations and develop product portfolios to meet consumer needs.

- Strengthening and adding marketing networks in all corners of the archipelago.

- Establish good relations with various government institutions, industry associations, non-governmental organizations, media, suppliers, consumers and fellow business actors as interacting parties in a dynamic social, political, economic and industrial environment.

In 2018, PT Arwana Citramulia Tbk applies several policies on the aspects of marketing and production, namely:

\section{Digital Product Development}

Digital products are the designation of PT Arwana Citramulia Tbk, which refers to ceramic products whose motives are printed using digital printing, which can print ceramics more efficiently, and produce better color quality. In 2018, PT Arwana Citramulia Tbk complements and adapts to customer needs through more varied ceramic colors, including the addition of pink to a size of $25 \times 25 \mathrm{~cm}$, and the addition of green to a size of $40 x 40 \mathrm{~cm}$. These variants get very positive responses from the market and loyal customers of PT Arwana Citramulia Tbk. For the UNO product line itself it has variations in size of $25 \times 25$, $25 \times 40,25 \times 50,40 \times 40$ and $50 \times 50 \mathrm{~cm}$. The portion of UNO's production grew from $31 \%$ in 2017 to $40 \%$ of total production in 2018 [6].
The process of adding motives from PT Arwana Citramulia Tbk itself is quite interactive, which involves customers, especially B2B ones in their market surveys. PT Arwana Citramulia throws a number of product design motifs first into the market, lets the market make a choice, then will produce several batches first to see the response from the market regarding the motives of new products. The investment made by PT Arwana Citramulia Tbk related to technology by conducting the procurement of digital print machines simplifies the process.

\section{E. Strengthening the Marketing Network}

One strategy in 2018 that affected the success of sales was the expansion of the distribution network within the domestic market. To ensure the distribution network works effectively and can anticipate market growth, in 2018, the Company opened a distribution network in Aceh and Singkawang. Nationally, the Company's consumers grew by $6 \%$ compared to the previous year. For the international market, in 2018 export expansion included the Republic of Yemen and Oman, from initially only to Malaysia, Brunei Darussalam, the Philippines, Mauritius, South Korea, and Pakistan. PT Arwana Citramulia's products get a positive response, which proves that PT Arwana Citramulia Tbk's products have good quality, designs that are in line with market tastes, and have high competitiveness [6].

The attraction of PT Arwana Citramulia's marketing network lies in how companies are able to manage and integrate the use of different channels to target the same target market. The complexity of the distribution flow and marketing network will be displayed in exhibit below.

\section{F. Increase Brand Awareness}

PT Arwana Citramulia Tbk made various efforts to continue to strengthen brand awareness, such as forming a merchandiser team specifically tasked with checking, maintaining, renewing ceramic displays in every store that sells Arwana and Uno products in Jabodetabek. PT Arwana Citramulia Tbk also develops brand awareness in various other ways, such as penetrating the use of applications for online catalogs that can be accessed through Android and iOS smartphones. The application is intended to make it easier for customers to see the latest motives and designs more quickly (PT Arwana Citramulia Tbk, 2018). The use of online channels such as online catalogs in the field proved to be very helpful in B2B marketing processes, especially from distributors to $\mathrm{B} 2 \mathrm{~B}$ customers, which will be displayed in exhibit below.

In addition to the use of applications, PT Arwana Citramulia Tbk also updates its account and maintains ongoing interactive communication on the company's social media, namely: Facebook: @arwanaceramicstiles and @unoceramicid, Twitter: @ arwana_ceramics and @uno_ceramics, YouTube: Arwana Ceramics and UNO Ceramics, Instagram: @Arwana_Ceramics and @UNO_Ceramics. 
Aside from social media, PT Arwana Citramulia Tbk also uses conventional promotional media such as advertising on billboards/ signboards, advertising on print media such as property magazines, and participating in national ceramics industry events such as Keramika. To increase brand awareness with other mediums, PT Arwana Citramulia Tbk established a non- profit sports organization in the field of table tennis called the Arwana Jaya Table Tennis Association or abbreviated as PTMAJ. In the beginning, PTMAJ was established as a hobby distribution activity for employees because of the high enthusiasm of employees in playing table tennis. Finally, PTMAJ has built and produced talented young athletes and many activities that have been followed nationally and internationally [6]. Efforts to increase brand awareness from PT Arwana Citramulia Tbk by using various channels of this type will be discussed in more detail later for discussion.

\section{G. Loyal Customer Retention Program}

One of the strengths of PT Arwana Citramulia Tbk is very strong customer engagement. PT Arwana Citramulia Tbk maintains and increases customer loyalty which in fact retail stores with interesting programs such as: giving appreciation to loyal customers of PT Arwana Citramulia Tbk. Customers get loyalty incentives with several levels where each level has its own benefits. The higher the level, the more benefits the customer gets, such as various prizes, incentive tours and spiritual trips [6].

In 2018 itself, PT Arwana Citramulia Tbk held a special event such as meeting with loyal customers in the Medan area to increase customer involvement. A meeting was also held with construction workers in the Jakarta, Surabaya and Lampung regions to increase their knowledge of the products produced by PT Arwana Citramulia Tbk. To further encourage customer loyalty, PT Arwana Citramulia Tbk also creates positive brand attitudes in interactions with customers, by giving personal touches such as birthdays and sending gifts or flowers at special events [6].

\section{$H$. Improvement of After Sales Service}

Aftersales services from PT Arwana Citramulia Tbk consist of a number of programs, which consist of Providing Toll-Free Customer Service telephone lines at 0.800.1.ARWANA. Telephone lines are useful for receiving information from consumers, either complaints against direct products or other things related.

\section{LITERATURE REVIEW}

\section{A. Omnichannel Marketing}

Omnichannel marketing is a form of marketing that uses various marketing channels to obtain, maintain, and develop customers from one market segment with integration between the channels used. In omnichannel marketing, there is integration between differences in design, distribution, coordination, and evaluation carried out by sellers and buyers. By focusing on managing the performance of each channel, the omnichannel marketing concept accepts the necessity that there is a need to use various channels, which are mutually integrated between the channels used, and adjust the channels used by the way consumers. Omnichannel marketing does not only discuss the distribution channels used by sellers so that products reach consumers but also about what channels sellers and consumers interact with [4]. [8] in his article shared the use of technology in the industrial era 4.0, which showed that the company had used omnichannel marketing; 1) the existence of technology that enhances in-store experience; 2) the use of technology that enhances online purchasing experience; and 3) technology that enhances cross-channel integration from an operational perspective.

As a method of marketing products, omnichannel marketing offers more complexity for the company, which can increase value for customers in shopping for a product from one company through 1) Adding and increasing touch points; the point of interaction or communication between the customer and the company; and 2) increasing the smoothness, or increasing the smoothness of the customer in accessing information about a product. Touch points and fluency are the determinants in increasing customer spending value; added value that increases the value received by the customer [1]. The value received by customers can increase because customers can reduce the non-monetary costs incurred in shopping, such as; effort, time, etc.

The use of large data in omnichannel marketing makes it easy for sellers to target markets specifically to be able to provide integrated services for certain target markets [9]. [6]mention the integration needed at several functional points of the company to be able to use omnichannel marketing which consists of:

1. Integrated promotion, refers to the integration between sources, channels, with the appearance or interface of promotional media used by companies in promoting their products.

2. Integrated transactions, referring to the integration of payment channels used by customers when buying products.

3. Integrated pricing, which refers to synchronizing the pricing of a product from one channel to the price of the same product sold on another channel.

4. Integrated fulfillment, is how companies can integrate several channels that are used related to product distribution functions from producers to consumers; including the convenience of consumers tracking goods, position, and shipping of goods.

5. Integrated product information, which is related to the similarity of information about the products offered on each channel used by the company.

6. Integrated customer service, which is related to the service or service function of the channel, where 
companies can integrate services such as means to complain, protest, and so on.

7. Integrated reverse logistics, referring to integration that aims to facilitate the process of retrieving, tracking and replacing related products. Available in distribution processes such as returns, stock storage, and product backflow.

Wiener, Hoßbach, \& Saunders (2018) added points about integration what could be a benchmark for whether a business has used omnichannel marketing or not, which in general would refer to the absence of conflicts between online and offline channels such as differences in demand between two channels, increasing complexity of flows operational, changes in staff skills needed, differences in work modes and priorities, price differences, cannibalism potential between channels.

The inter-channel problem as mentioned by Wiener, Hoßbach, \& Saunders, can be overcome by integrating between the channels used in [2]: 1. Channel stages; integration is carried out on stages, whether at the level of pre-purchase, payment, delivery or return if any. 2 . Channel types; integration in channel types; online, offline, mobile, up to all three combinations. 3. Channel agents; where integration occurs in each agent that becomes a company's supply chain line. Ideally, omnichannel marketing occurs when the three channels mentioned by [6] are integrated with one another but do not rule out the possibility that often only one or two types of integration occur; both on stages, types, and agents. The use of omnichannel marketing will lead to how a business integrates each different marketing channel based on its function, which when referring to [10] writing is simplified into 3 ; 1) communication channel; 2) distribution channel; and 3) service channel. A Communication channel is a channel used to send and receive messages to target buyers, including newspapers, magazines, radio, television, internet, billboards, posters, and so on. Communication here also contains product information, to communicate products to customers. Distribution channels are channels that are used to display, sell or send goods or services to consumers. This channel can be used directly through online ordering, direct shipping, or indirectly through wholesalers, retailers, or agents as intermediaries [8]. In the [6] article, this function is divided into fulfillment and reverse logistics. Service channels are the channels chosen to make transactions, including the matter of banks, and insurance companies. Integrated use of online and offline channels for each channel in omnichannel marketing is expected to provide maximum results in the use of these 3 channels, which is still a problem that is often faced by business people who use multichannel marketing. Exhibit 1 shows the omnichannel marketing model used by Saghiri and became a reference in this study.

\section{B. Technology Acceptance Model}

Technology acceptance model, or hereinafter referred to as TAM, is a research model initiated by Fred D. Davis in 1985. The basic model of TAM was originally developed for the context of acceptance of computer technology, which is now increasingly widespread up to the use of system acceptance in an organization [4].

The TAM model generally explains that motivation to use systems are intermediaries between features in a system, with actual system use that can measure how technology can be applied in an organization [11]. The technological context in the organization mentioned by Davis also covers how technology can help internal relations with the external, one of which is to assist sales. As time goes on, TAM is increasingly being developed, adjusting to the context of research conducted by researchers but still at the core of TAM itself, namely how the design stimulates user motivation that can consist of cognitive and affective response, then affects the behavioral response in the form of using technology.

In the initial model, TAM measures a number of variables, which then will lead to perceived usefulness and perceived ease of use of a technology [11]. Some articles developed the model according to the context of the research, one of which was conducted by [9] when researching online reviews of acceptance of AR features in the IKEA catalog. Research using TAM with simple adjustments is in the form of a direct correlation from the usefulness to the intention to use without passing attitude. Another form of TAM variation is as in the research conducted by [7] which developed TAM for the B2B marketing context. The model given is in the form of additional response in the form of usability, with features such as learnability, efficiency, memorability, error, and satisfaction that can affect the usability or usability of a technology to improve business performance. TAM will be used to measure how the channel agent accepts the use of one channel type, namely arwana and uno ceramics applications that are used integrated in b2b marketing activities carried out offline.

\section{METHOD}

In working on this case study, researchers will use research methods that combine quantitative methods with qualitative methods, which use data obtained through unstructured interviews. The use of the combination of data was chosen to be able to understand a problem more thoroughly, can see from various perspectives, and try to reduce the bias that might occur in a study because it sees a phenomenon more thoroughly [12]. The data that obtained with unstructured interviews and quantitative methods also has a higher accuracy in providing an overview of social dynamics in society [13]. This research will refer to several previous studies; so that researchers will combine a number of previous studies that also discuss omnichannel 
marketing and technology acceptance models especially for B2B marketing activities.

Because the sample in this study is limited to Pareto stores and the main distributors of PT Arwana Citramulia Tbk, researchers can still use unstructured interviews with participant observation to see how large distributors and retailers or pareto stores use and integrate channels to B2B marketing activities. According to [20], unstructured interview is a method used to collect data in depth using depth interviews, which can provide additional data to be analyzed quantitatively. Although referred to as unstructured, unstructured interviews still depart from the operationalization of the concept of omnichannel marketing, which is a guideline for researchers in directing informal and wrapped conversations such as chat so as to give respondents the freedom to provide answers [17]. To complete the unstructured interview, researchers will also conduct participant observation where researchers are directly involved in data collection in the field, so they can observe the dynamics that occur, especially about how the reaction, the flow of purchases, and what happens in $\mathrm{B} 2 \mathrm{~B}$ marketing activities at the distributor and pareto level which sells Arowana and Uno Tiles ceramics.

Quantitative model used in this research are use technology acceptance model, as shown at exhibit 2. TAM used to measure how the ease of use and usefulness of the application create an salesperson intention to use digital aplication in b2b marketing activities. Learnability, Error, Informativeness, Enjoyment and Efficiency is the feature that used to measure the usefulness and efficiency for the digital application. PLS SEM is used with $n=30$ for quantitative analysis, and $n=28$ for qualitative analysis.

Sampling use the quota method, which is the sample reference number by following the rule of thumb for research using PLS-SEM; namely $3 *$ formative construct [14]. Referring to the picture of this research model shown in Figure 3.2, there are 3 formative constructs; Perceived Usability or Ease of Use, Perceived Usefulness, and Intention of Use. Thus, the number of samples for the quantitative method and analyzed using PLS-SEM is $\mathrm{n}=$ 30, where the questionnaire will be filled by the person in charge of the distributor, the owner of the Pareto store, and the salesperson responsible for selling Arwana and Uno Tiles products. The qualitative method used in this research obtained from the salesperson, store owner, or person in charge in selling products in b2b context. Due to condition, this research only get 28 sample for qualitative data from 30 sample used in quantitative data plus data from the CEO, Mr Tandean Rustandy, M.B.A.

The qualitative method used in this study is applied in form of checklist indicator for omnichannel marketing from the previous research from [6] and [8]. Table 2 show the indicator used in this research to confirm how much the company use an omnichannel marketing.
TABLE 1.

DATA TYPE AND SAMPLE

\begin{tabular}{llc}
\hline \hline Data Type & Sample & Scope \\
\hline Quantitative & $\mathrm{n}=30$ & Jakarta \& Bekasi \\
Qualitative & $\mathrm{n}=28$ & \\
\hline \hline
\end{tabular}

TABLE 2.

INDICATOR CHECKLIST FOR OMNICHANNEL MARKETING

\begin{tabular}{cl}
\hline \hline Reference & \multicolumn{1}{c}{ Indicator } \\
\hline & Integration between channel stages \\
& Integration between channel types \\
& Integration between channel agents \\
& Integrated promotion \\
& Integrated transaction \\
& Integrated pricing \\
& Integrated fulfillment \\
& Integrated product information \\
& Integrated customer services \\
& Integrated reverse logistics \\
\hline & The use of technology that improve store experience \\
& The use of technology that improve online shopping \\
& experience \\
& The use of technology that improve operational \\
\hline \hline
\end{tabular}

\section{RESULTS AND DISCUSSIONS}

\section{A. Results}

The loading indicator shows the strength of each indicator against the variable. Of the 27 indicators used, 2 indicators are below the default standard SmartPLS 3 which is at point 0.7 . For the composite reliability, an instrument is declared reliable when obtaining results above 0.7. Average Variance Extracted of the instrument also got above 0.5 , as shown in Table 3 .

Based on the PLS-SEM test results with SmartPLS 3, this research obtained $\mathrm{R}^{2}$ value for Perceived Usability of 0.655, which is shows that learnability, error, enjoyment, informativeness, and efficiency have an influence on perceived usability by $65 \%$. Perceived Usefulness variable obtained an $\mathrm{R}^{2}$ value of 0.323 , which means that efficiency and informativeness have an effect of $32.3 \%$ on the perceived usefulness of omnichannel marketing in B2B marketing activities for Arwana and Uno Tiles products for distributors and Pareto stores in Bekasi and Jakarta. For Intention to Use, $\mathrm{R}^{2}$ obtained a value of 0.625 , which means that perceived usability and perceived usefulness of the use of catalogs in applications in an integrated manner with store sales and B2B marketing activities have an influence on the intention to use of the store owner and salesperson to began to integrate the use of online channels in B2B marketing activities at $62.5 \%$. 
The $1^{\text {st }}$ International Conference on Business and Management of Technology (IConBMT)

August 3rd 2019, Institut Teknologi Sepuluh Nopember, Surabaya, Indonesia

TABLE 3.

COMPOSITE RELIABILITY AND AVE

\begin{tabular}{|c|c|c|c|c|}
\hline \multirow{2}{*}{ Variable } & \multirow{2}{*}{ Item } & \multirow{2}{*}{$\begin{array}{c}\text { Indicator } \\
\text { Loading }\end{array}$} & \multirow{2}{*}{$\mathbf{C R}$} & \multirow{2}{*}{ AVE } \\
\hline & & & & \\
\hline \multirow{3}{*}{ Learnability } & L1 & 0.932 & \multirow{3}{*}{0.96} & \multirow{3}{*}{0.889} \\
\hline & $\mathrm{L} 2$ & 0.962 & & \\
\hline & L3 & 0.933 & & \\
\hline \multirow{3}{*}{ Error } & Er1 & 0.625 & \multirow{3}{*}{0.838} & \multirow{3}{*}{0.64} \\
\hline & Er2 & 0.791 & & \\
\hline & Er3 & 0.964 & & \\
\hline \multirow{4}{*}{ Enjoyment } & En1 & 0.929 & \multirow{4}{*}{0.9} & \multirow{4}{*}{0.695} \\
\hline & En2 & 0.846 & & \\
\hline & En3 & 0.752 & & \\
\hline & En4 & 0.797 & & \\
\hline \multirow{3}{*}{ Informativeness } & I1 & 0.556 & \multirow{3}{*}{0.798} & \multirow{3}{*}{0.576} \\
\hline & $\mathrm{I} 2$ & 0.814 & & \\
\hline & I3 & 0.87 & & \\
\hline \multirow{3}{*}{ Efficiency } & Ef1 & 0.863 & \multirow{3}{*}{0.912} & \multirow{3}{*}{0.775} \\
\hline & Ef2 & 0.9 & & \\
\hline & Ef3 & 0.877 & & \\
\hline \multirow{4}{*}{ Perceived Usability } & Usb1 & 0.734 & \multirow{4}{*}{0.878} & \multirow{4}{*}{0.645} \\
\hline & Usb2 & 0.822 & & \\
\hline & Usb3 & 0.869 & & \\
\hline & Usb4 & 0.779 & & \\
\hline \multirow{4}{*}{ Perceived Usefulness } & Usf1 & 0.771 & \multirow{4}{*}{0.892} & \multirow{4}{*}{0.67} \\
\hline & Usf2 & 0.833 & & \\
\hline & Usf3 & 0.851 & & \\
\hline & Usf4 & 0.826 & & \\
\hline \multirow{3}{*}{ Intention to Use } & IU1 & 0.855 & \multirow{3}{*}{0.893} & \multirow{3}{*}{0.735} \\
\hline & IU2 & 0.828 & & \\
\hline & IU3 & 0.889 & & \\
\hline \multicolumn{5}{|c|}{$\begin{array}{c}\text { TABLE } 4 . \\
\mathrm{R}^{2} \\
\end{array}$} \\
\hline & & $\mathbf{R}^{2}$ & $\mathbf{R}^{2}$ Adjusted & \\
\hline Perceived Usability & & 0.655 & 0.583 & \\
\hline Perceived Usefulnes & & 0.323 & 0.215 & \\
\hline Intention to Use & & 0.625 & 0.597 & \\
\hline
\end{tabular}

The path coefficient describes the strength of the relationship between variables in the study. In this study, the relationship between efficiency variables and perceived usefulness has a negative coefficient. This can be interpreted that the level of efficiency of the use of Arwana Ceramics and Uno Tiles applications is not statistically considered to have usefulness for the respondents. Negative coefficients were also found for enjoyment variables with perceived usability. It can be interpreted that the enjoyment of respondents in using the application does not have a positive influence on the ease of operating the Uno Tiles and Arwana Ceramics applications. The results of data processing with SmartPLS indicate that the intention to use of the salespersons and other individuals who are channel agents from PT Arwana Citramulia Tbk in Jakarta and Bekasi to use online channels are based on the perceived usefulness of online catalog applications, followed by perceived usability from the application. The path coefficient can be seen at exhibit 3 .

Integration in the marketing channel carried out by PT Arwana Citramulia Tbk is a manifestation of the strategy stated in the annual report in 2018, regarding the efforts of PT Arwana Citramulia Tbk in improving the performance of marketing and product distribution aspects, especially to maintain loyalty from B2B customers. The use of marketing channels by PT Arwana Citramulia Tbk, which are mutually integrated between channel types, channel agents on the channel stage show forms of omnichannel marketing. The absence of conflict or competition between channels is also an indication that there is integration in the use of channels used by PT Arwana Citramulia Tbk. The CEO of PT Arwana Citramulia Tbk, Mr. Tandean Rustandy, M.B.A stated how he could create integration between the channels used without creating inter-channel conflicts.

"The stores in Jakarta is loyal because of the money.

They are loyal because I condition so that they don't

have rivals in their territory, so they are loyal to Arowana"

CEO of PT Arwana Citramulia Tbk, Mr. Tandean Rustandy, M.B.A

The remarks were made on Thursday, April 25, 2019, in the 2017-2 MM UI marketing class mentoring session which was followed by researchers. During the session, Mr. Tandean Rustandy, M.B.A. also added that the loyalty of B2B customers in the form of Pareto stores and retail stores due to products from PT Arwana Citramulia Tbk that entered their stores could be sold quickly. One of the reasons that the products can be sold quickly at the Pareto store is what was mentioned by Mr. Tandean Rustandy, M.B.A. regarding the absence of competition in one region. In terms of channel type, some salespersons can also use the channel type in the form of online and medium offline catalogs in B2B sales activities as stated in the results of the quantitative data processing above.

Exhibit 4-6 showed us about the findings about the complexity of omnichannel channel management that PT Arwana Citramulia Tbk used so they can achieve minimum to zero conflicts between channel agent and push them to integrate one with another, also integrate the usage of online and offline channel.

The qualitative data analysis also shown that PT Arwana Citramulia Tbk get $100 \%$ on the indicator checklist for implementation of omnichannel marketing according to [6] and [8]. For the distribution chain such as Pareto store and sub distributor in Jakarta and Bekasi, the lowest results are $46 \%$ for Bekasi, and $84 \%$ for Jakarta. The qualitative data also support the quantitative analysis results; which is the 
intention to use mobile apps for implementing omnichannel marketing in b2b marketing activities influenced mostly from usefulness of the application for the user. The salesperson prefer the apps that can help them sell the products, but also mention the ease of use of using the digital catalogue.

"If you ask the salesperson, they will all answer positively. They are those who use the application. So they are easier to go around for selling the product. But, there must be ups and downs. The current application is still inadequate to use. It still need a lot of improvement"

Mr. Eldy, Primagraha Keramindo Salesperson

Besides of the improvement that the application needed so it it can give more perceived usefulness for the salesperson as user, many stores also provide us with an advanced idea about omnichannel marketing application in their store. For example, one store in Jakarta, Dwi Jaya seems enthusiast about usage of technology in marketing. The owner states that

\begin{abstract}
"(Enthusiastically speaking to Mr. Eldy and the researcher) this way, if the application is like this it is good if you can use it to the monitor too. I see the monitor is already there (pointing to the monitor at the payment desk) later if people want to buy ceramics, I can point to the mockup. Or later I will install it in the Uno window (pointing to the display) so the customer can think about how to use this ceramic. Then if there is an AR feature, you can add a set model (referring to competitor ceramics that has a set of floors and walls) so that it connects and helps the customer choose. One more thing I think about is the location feature, so for example, people want to sell ceramics, when they type in the location of Rawa Buaya, our store comes out. So it'll easier for the consumer."
\end{abstract}

Mr. Nicky, Owner of Dwi Jaya Material Store, Jakarta

When it come to the technology, most of the store owner or the salesperson that younger than 40 are tech savvy, and didnt find any significant difficulties when it come to use an mobile application. It is pretty different from one store in Bekasi, which only get $46 \%$ on the indicator checklist. The salesperson that we interviewed stated:

\footnotetext{
"I don't understand if it's come to online thing. Here, people just bring the ceramics as an example if they want to buy."
}

\section{Salesperson at Bursa Keramik, Bekasi}

Another thing should be noted is geographic location of the store, demographic of the store owner and the salesperson, also the psychographic. The difference in response is significant, which is shown that eventhough Bekasi just $20 \mathrm{~km}$ from Jakarta, but not everyone as tech savvy as the people in Jakarta, in term of the salesperson or the owner of material store. This is a note for the application developer and Primagraha Keramindo, that their application still not that easy to use/ didnt have pretty much usability for the user.

\section{B. Discussions}

Many of the salespersons said that the applications that were available had several disadvantages, starting from the weight when loading images, there was no feature to zoom in to see details, mockup features that could not be used, and provide some input for future application development, such as; where customers can buy products, better rendering results, and the presence of apps for sales to be able to monitor the capacity of goods in real time will be very helpful when sales are asked about the availability of certain ceramic units. The idea of using the AR feature in the application had been thrown several times, which was responded positively by the salesperson and store owner. The feature is expected to provide product knowledge about product details further, such as dimensions, ceramic luster, weight, and what if the motif is installed in the location desired by the customer. This explain the quantitative analysis that shown the perceived usefulness of the omnichannel marketing by using technology still only get 59\% path coefficient, and 39\% path coefficient for the perceived usability. PT Arwana Citramulia Tbk needs improvement in their application to support what the salesperson, as the user, needs.

\section{Limitations}

This study has several limitations, both in terms of the research context of the research methodology.

- In terms of the research context, this study only addresses one case; regarding how PT Arwana Citramulia Tbk manages its channel, in one research context, namely PT Arwana Citramulia Tbk.

- This research is only conducted in the marketing field of PT Arwana Citramulia Tbk, without paying attention to other support systems, especially from other fields and functions that support the successful management of the channel carried out by PT Arwana Citramulia

\section{CONCLUSIONS}

Related to the formulation of the problem "How does PT Arwana Citramulia Tbk apply channel usage in an integrated manner to all distribution chains below? ", It can be concluded that PT Arwana Citramulia Tbk can implement omnichannel marketing well. The use of omnichannel marketing conducted by PT Arwana Citramulia starts from the level of the company's strategy; to strengthen marketing networks, modernize warehouse management, and establish good relations is a form of a strategy used by companies to achieve superior profitability compared to its competitors. From the level of strategy, then it is lowered to the functional level, namely the marketing field. The marketing activities of PT Arwana Citramulia Tbk products are carried out by PT Primagraha Keramindo with regional sales, which are forwarded to PT 
Catur Sentosa Adiprana to reach small retail store customers or approach Pareto stores in several regions. Deliveries for Pareto stores are done directly from the factory, in contrast to small retail stores that get shipments of goods from PT Catur Sentosa Adiprana's warehouse. However, payments are made through one door, namely through the PT Catur Sentosa Adiprana region. Integration and lack of inter-channel conflict can be achieved thanks to the clear division of territories and roles, which are also maintained by PT Arwana Citramulia Tbk through the sales and merchandiser team of PT Primagraha Keramindo.

For the second problem "How do large distributors and retail stores use the channels provided by PT Arwana Citramulia Tbk in their B2B marketing activities", based on the results of interviews and observations made, ceramics are products that still require physical form, so it is very appropriate when using online channels such as applications to help with sales activities, which also carry sample products. From the results of quantitative data using the model technology acceptance made to salespersons and individuals who conduct B2B sales activities, it was found that the intention to use of online catalog applications was positively influenced by the ease of using the application and how efficient the application helped sales in carrying out sales tasks for B2B marketing.

\section{ACKNOWLEDGEMENT}

Hatur nuhun Mr Daniel Tumpal H. Aruan for all the guidance and helps, Mr Tandean Rustandy and crew from PT Arwana Citramulia Tbk for their support and access for data.

\section{REFERENCES}

[1] J. M. Müller, O. Buliga, and K. I. Voigt, "Fortune favors the prepared: How SMEs approach business model innovations in Industry 4.0," Technol. Forecast. Soc. Change, vol. 132, pp. 217, Jul. 2018.

[2] V. Krotov, "The Internet of Things and new business opportunities," Bus. Horiz., vol. 60, no. 6, pp. 831-841, Nov. 2017.

[3] O. C. Walker and J. W. Mullins, Marketing Strategy: A Decision-Focused Approach. New York: McGraw-Hill Irwin, 2014.

[4] K. L. Ailawadi and P. W. Farris, "Managing multi- and omnichannel distribution: Metrics and research directions," J. Retail., vol. 93, no. 1, pp. 120-135, Mar. 2017.

[5] E. Huré, K. Picot-Coupey, and C. L. Ackermann, "Understanding omni-channel shopping value: A mixed-method study," J. Retail. Consum. Serv., vol. 39, pp. 314-330, Nov. 2017.

[6] S. Saghiri, R. Wilding, C. Mena, and M. Bourlakis, "Toward a three-dimensional framework for omni-channel," J. Bus. Res., vol. 77, pp. 53-67, Aug. 2017.

[7] E. Lacka and A. Chong, "Usability perspective on social media sites' adoption in the B2B context," Ind. Mark. Manag., vol. 54, pp. 80-91, Apr. 2016

[8] F. von Briel, "The future of omnichannel retail: A four-stage Delphi study," Technol. Forecast. Soc. Change, vol. 132, pp. 217-229, Jul. 2018.

[9] A. Rese, S. Schreiber, and D. Baier, "Technology acceptance modeling of augmented reality at the point of sale: Can surveys be replaced by an analysis of online reviews?," J. Retail. Consum. Serv., vol. 21, no. 5, pp. 869-876, 2014.

[10] P. Kotler and K. L. Keller, Marketing Management, 15th ed. Boston: Pearson, 2016.

[11] PT Arwana Citramulia Tbk, “Annual Report PT Arwana Citramulia Tbk 2018," Jakarta, 2018.

[12] A. A. Thompson, M. A. Peteraf, J. E. Gamble, and A. J. Strickland, Crafting \&amp; Executing Strategy: The Quest For Competitive Advantage,Concepts And Cases. New York: McGraw-Hill Education, 2018.

[13] T. M. Taufique Hossain, S. Akter, U. Kattiyapornpong, and S. F. Wamba, "The impact of integration quality on customer equity in data driven omnichannel services marketing," Procedia Comput. Sci., vol. 121, pp. 784-790, 2017.

[14] F. D. Davis, "A technologyacceptancemodel for empirically testing new end-user information system: Theory and results," Massachusetts Institute of Technology, 1985. 
The $1^{\text {st }}$ International Conference on Business and Management of Technology (IConBMT)

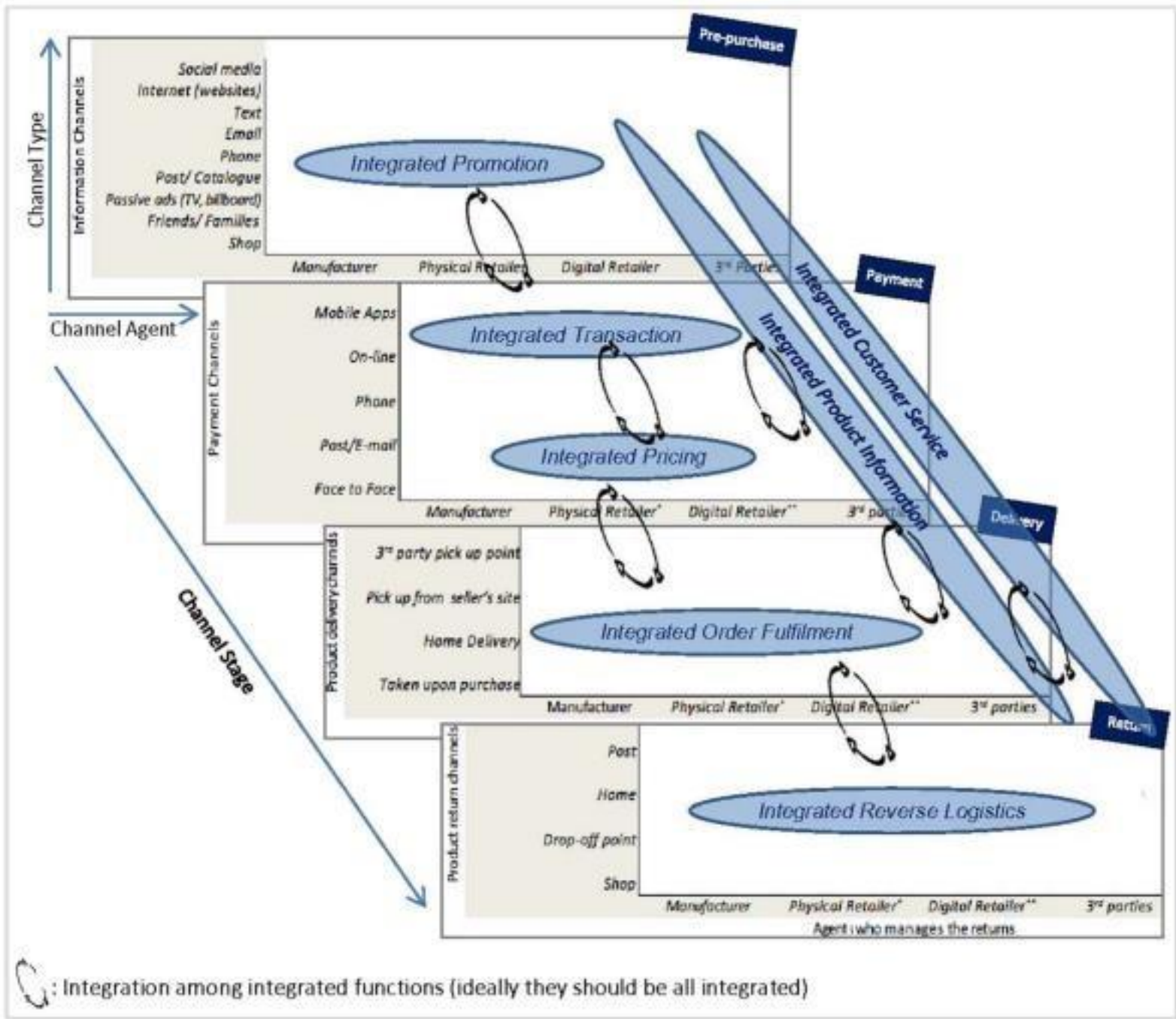

Exhibit 1. Integration in omnichannel marketing according to Saghiri, 2017.

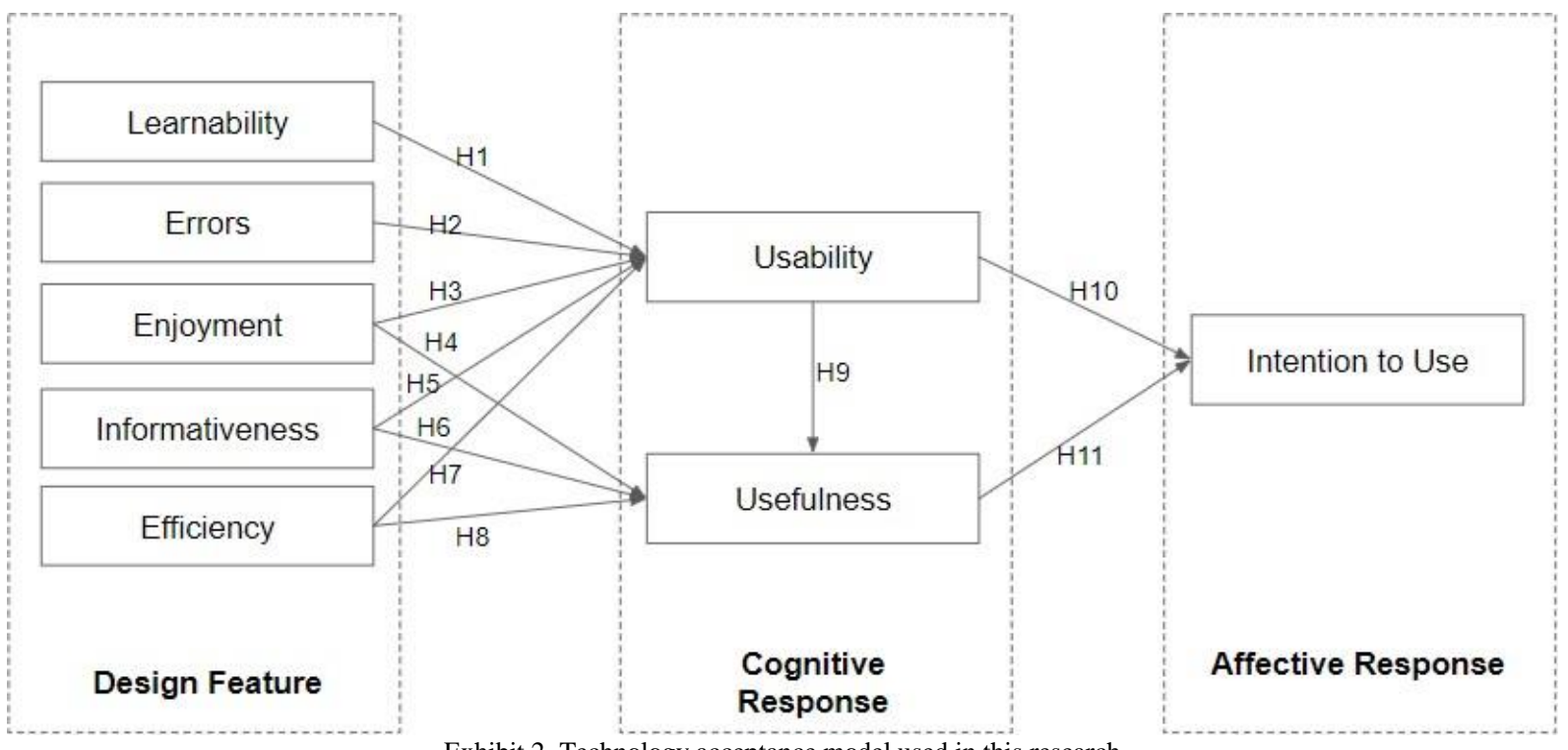

Exhibit 2. Technology acceptance model used in this research 
The $1^{\text {st }}$ International Conference on Business and Management of Technology (IConBMT)

August 3rd 2019, Institut Teknologi Sepuluh Nopember, Surabaya, Indonesia

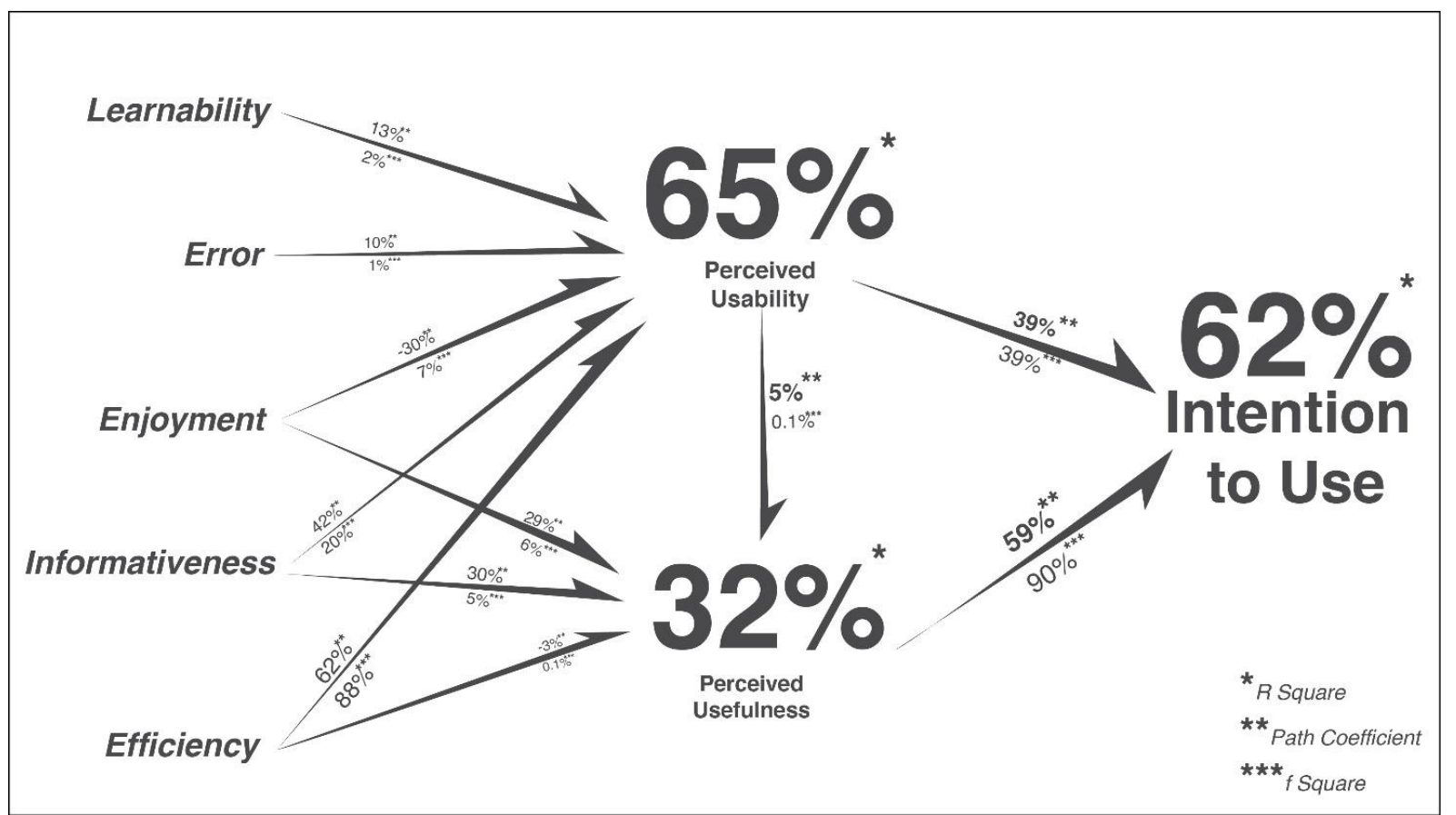

Exhibit 3. $\mathrm{R}^{2}$, Path Coefficient, and $\mathrm{f}^{2}$ value

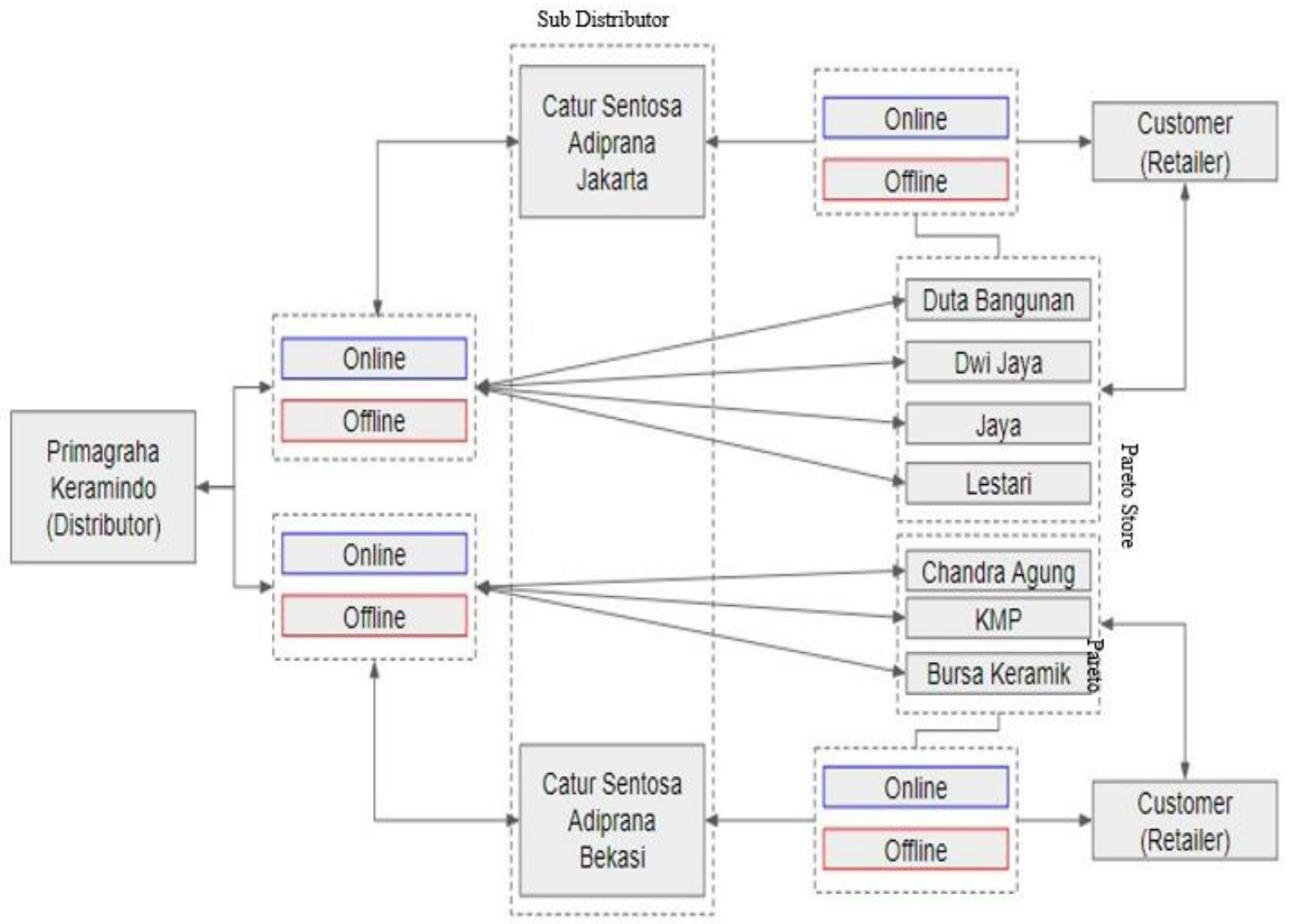

Exhibit 4. Product information, Customer Services, and Promotion flow in PT Arwana Citramulia Tbk marketing channel 
The $1^{\text {st }}$ International Conference on Business and Management of Technology (IConBMT) August 3rd 2019, Institut Teknologi Sepuluh Nopember, Surabaya, Indonesia

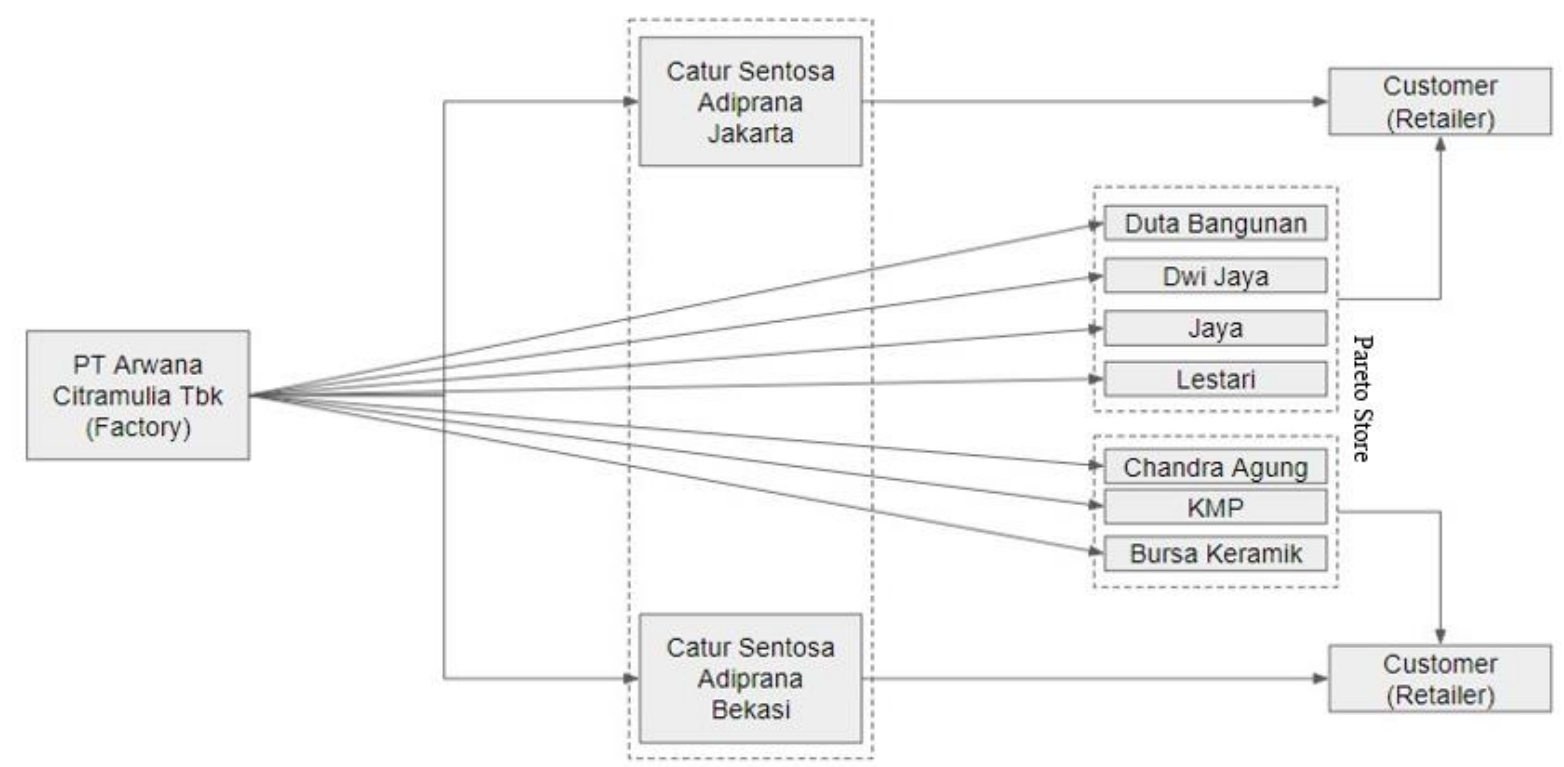

Exhibit 5. Product distribution flow in PT Arwana Citramulia Tbk marketing channel

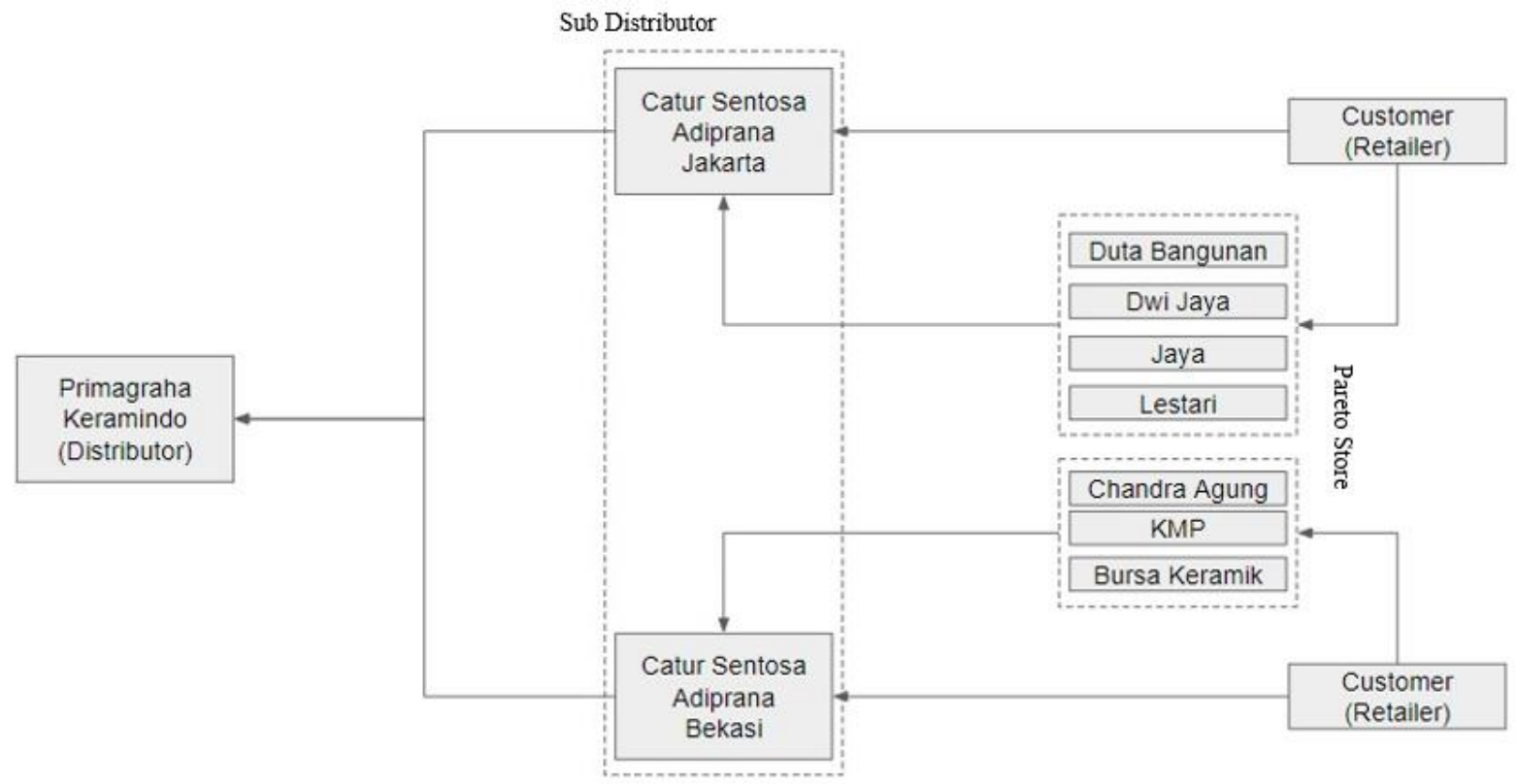

Exhibit 6. Transaction flow in PT Arwana Citramulia Tbk marketing channel 